\title{
Root reinforcement and slope bioengineering stabilization by Spanish Broom (Spartium junceum L.)
}

\author{
F. Preti and F. Giadrossich \\ Dipartimento di Ingegneria Agraria e Forestale, Università degli studi di Firenze, Florence, Italy \\ Received: 6 May 2009 - Published in Hydrol. Earth Syst. Sci. Discuss.: 29 May 2009 \\ Revised: 27 August 2009 - Accepted: 3 September 2009 - Published: 29 September 2009
}

\begin{abstract}
The present paper deals with the root system's characteristics of Spanish Broom (Spartium junceum L.), a species whose capacity for adaptating and resisting to drought is worth investigating. In particular, the aims of the study were 1) to investigate the plant's bio-mechanical aspects and 2) to verify whether root reinforcement and the field rooting ability of stem cuttings enhance its potential for use in slope stabilization and soil bio-engineering techniques, particularly in the Mediterranean areas.

Single root specimens were sampled and tested for tensile strength, obtaining classic tensile strength-diameter relationships. Analysis were performed on the root systems in order to assess root density distribution. The Root Area Ratio (RAR) was analyzed by taking both direct and indirect measurements, the latter relying on image processing. The data obtained were used to analyze the stability of an artificial slope (landfill) and the root reinforcement. The measurement and calculation of mean root number, mean root diameter, RAR, root cohesion and Factor of safety are presented in order to distinguish the effect of plant origin and propagation.

Furthermore, tests were performed to assess the possibility of agamic propagation (survival rate of root-ball endowed plants, rooting from stem cuttings). These tests confirmed that agamic propagation is difficult, even though roots were produced from some buried stems, and for practical purposes it has been ruled out.

Our results show that Spanish Broom has good biomechanical characteristics with regard to slope stabilization, even in critical pedoclimatic conditions and where inclinations are quite steep, and it is effective on soil depths up to about $50 \mathrm{~cm}$, in agreement with other studies on Mediter-
\end{abstract}

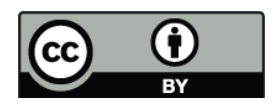

Correspondence to: F. Preti (federico.preti@unifi.it) ranean species. It is effective in slope stabilization, but less suitable for soil bio-engineering or for triggering natural plant succession.

\section{Introduction}

Soils covered by vegetation run less risk of erosion from both water and land movement (Burroughs and Thomas, 1977; Ziemer, 1981; Sidle et al., 1985; Greenway, 1987; Coppin and Richards, 1990; Gray and Sotir, 1996). The role roots play in slope stabilization has been recognized for many years (e.g. Gray and Sotir, 1996; Gray and Leiser, 1982), whereas interest in bio-mechanical tests on roots (of Mediterranean species in particular) has arisen only in more recent years (Operstein and Frydman, 2000; Mattia et al., 2005; Tosi, 2007; De Baets et al., 2008). De Baets et al. (2007, 2008) showed how some typical Mediterranean plants increase topsoil resistance to erosion and shallow landslides from runoff and superficial flow.

As one can see in Table 1, some Mediterranean species were subjected to root tensile strength, shear stress and/or pull-out tests, and also the architecture of their rooting system grown on slopes was studied. Spanish Broom (Spartium junceum L.) has been studied by Chiatante et al., 2001, 2003a, b with regard to the architecture of the Spanish Broom root system when grown on slopes: it has been observed that its orientation and root density undergo a modification. Its root growth is asymmetric and follows the orientation of the slope, concentrating mainly on the uphill direction (if we consider the stem). This is a characteristic that guarantees the stability of the plant (Chiatante et al., 2001, 2003a, b; Di Iorio et al., 2005). Also Norris and Greenwood (2003), Laranci et al. (2004) and Tosi (2007) have studied Spanish broom. 
Table 1. Mediterranean species studied by other authors.

\begin{tabular}{|c|c|}
\hline Autors & Studied plants \\
\hline Operstein and Frydman (2000) & $\begin{array}{l}\text { Medicago sativa, Rosmarimus officinalis, Pistacia lentiscus e Cistus } \\
\text { (all dicotyledonous shrub species) }\end{array}$ \\
\hline Gallotta et al. $(2000,2003)$ & Cupressus, Crataegus, Juglans, Prunus, Pyrus, morus, tamarix \\
\hline Amato et al. $(1997,2000)$ & $\begin{array}{l}\text { Citrus sinensis, Prunus avium, Ailanthus altissima, Castanea sativa, Ficus carica, Pinus, } \\
\text { Quercus pebescens, Prunus, Arundo, Festuca, Poa, Dactylis, Trifolium, } \\
\text { Cyclamen, Brassica and Rubus frutticosus }\end{array}$ \\
\hline Mattia et al. (2005) & Lygeum spartum L. (herb), Atriplex halimus L. and Pistacia lentiscus L. (shrub) \\
\hline De Baets et al. (2008) & $\begin{array}{l}\text { Atriplex halimus (shrub), Salsola genistoides (shrub), Brachypodium retusum (grass), Thymelaea } \\
\text { hirsuta (shrub), Phragmites australis (reed), Limonium supinum (herb), Tamarix canariensis (tree), } \\
\text { Artemisia barrelieri (shrub), Stipa tenacissima (grass), Juncus acutus (rush), Fumana } \\
\text { thymifolia (shrub), Dorycnium pentaphyllum (shrub), Teucrium capitatum (shrub), Dittrichia } \\
\text { viscosa (shrub), Thymus zygis (shrub), Lygeum spartum (grass), Plantago albicans (herb), } \\
\text { Rosmarinus officinalis (shrub), Helictotrichon filifolium (grass), Piptatherum miliaceum (grass), } \\
\text { Avenula bromoides (grass), Nerium, oleander (shrub), Ononis tridentata (shrub), } \\
\text { Anthyllis cytisoides (shrub), Retama sphaerocarpa }\end{array}$ \\
\hline Laranci et al. (2004) & $\begin{array}{l}\text { Phillirea latifolia, Rhamnus alaternus, Viburnum tinus, Euonymus europaeus, Coronilla emerus, } \\
\text { Pistacia terebinthus, Acer campestre and Spartium junceum }\end{array}$ \\
\hline Tosi (2007) & Rosa canina, Inula viscosa and Spartium junceum \\
\hline Chiatante et al. $(2001,2003 a, b)$ & architecture of the Spartium junceum L. rooting system grown on slopes \\
\hline
\end{tabular}

In general, the development of the root system is influenced by genetic and environmental factors, e.g. its lignin and cellulose content, soil structure and texture, temperature and water availability, seasons and altitude (Genet et al., 2005).

In nature a wide variety of root systems can be observed, both on a horizontal and on a vertical plane (Stokes et al., 2008). Consequently, their impact on soil reinforcement is somewhat heterogeneous. Moreover, they increase the resistance of top-soil to erosion and finer roots have a higher tensile strength per cross section unit area (Gray and Leiser, 1982; Operstein and Frydman, 2000). On the other hand, thicker roots can be likened to biological nails, which probably tend more to pull out than to break (Coppin and Richards, 1990; Greenwood, 2005); thicker roots use just a small part of their tensile strength (Burroughs and Thomas, 1977; O'Loughlin and Watson, 1979; Ziemer, 1981; Schmidt et al., 2001). De Baets et al. (2008) highlighted the importance of fine roots. The literature also reports that as root tensile strengths are usually measured in tens or hundreds of megapascals and soil shear strengths are normally in the range of tens of kilopascals, interspecies differences in the tensile strength of living roots are probably less significant to slope stability than are interspecies differences in root distribution (Abernethy and Rutherford, 2001).

Wu (1976) and Wu et al. (1979) pioneered a model that was applied in numerous studies for the assessment of how roots contribute to soil shear reinforcement. The impact of root reinforcement on soil is generally expressed as an increase in soil cohesion (Borroughs and Thomas, 1977; Wu et al., 1979; Wu, 1984a, b; Sidle et al., 1985; Sidle, 1992; Wu and Sidle, 1995; Abernethy and Rutherford, 2001; Stokes et al., 2007; Stokes et al., 2008 in Norris et al., 2008). A number of factors influence the tensile strength test: species, season, age, soil compaction, deformation of roots, soil and root moisture, root preservation, field or lab test, type and size of testing equipment, root clamping procedure, test speed, and rate of elongation (Rienstenberg, 1994; Cofie and Koolen, 2001; Fan and $\mathrm{Su}, 2008$ ).

The planting method, quality of planting and root pruning (undercutting) influence the root development when establishing a planted stand. Three main methods can be used: direct seeding on site, transplanting of seedlings sown in containers, planting of bare-root seedlings and transplanting of cuttings (bare-root or in containers) (Stokes et al., 2008).

Various studies have documented the good results obtained by using Spanish Broom to recover badlands. This species has a marked adaptability and resistance to drought. Its thick covering makes it appropriate for protecting slopes that show superficial erosion phenomena (Leopardi, 1845; Bagnaresi et al., 1986; La Mantia and La Mela Veca, 2004; Tosi, 2007).

Such studies used seed plants, plants with a root ball and plants with bare roots. Laranci et al. (2004) studied the survival of rooted plants and their ability to develop adventitious 
roots after burying a portion of the stem. This study used rooted plants grown in pots. Tests showed that, once planted, Spanish Broom cannot develop adventitious roots from its stem. However, its root system can develop quite satisfactorily, and it grows more than in other species.

Morone et al. (2005) and AA.VV. (2006) conducted some micropropagation tests on Spanish Broom plants. Auxinic plant growth regulators were used at different concentrations (indoleatic acid, IAA, and indolebutyric acid, IBA) to induce rhizogenesis in green stem cuttings. This protocol allows a high rate of young plants production in a short period of time. Quatrini et al. (2002) proposed using plants that were inoculated with nitrogen-fixing bacteria.

The paper is structured as follows: in Materials and methods Section we describe the study area (hydrology, soils), and investigated plants (roots distribution, lab tensile tests, roots reinforcement and plant propagation). The obtained results are presented and finally, these results are discussed and conclusions drawn.

\section{Materials and methods}

The present study focused on this typical Mediterranean species and studied the following features on an experimental basis by distinguishing transplanted and spontaneous Spanish Broom specimens: its bio-mechanical characteristics, the spatial distribution of its roots and the statistical variability of RAR at each depth. Root tensile strength tests were carried out using devices that were custom-built in our Faculty laboratories. In addition, we calculated the Factor of safety (Fs) of the slope. For the calculation of supplementary cohesion, the well-known Wu and Waldron formula was adopted for each soil horizontal cross section and the conditions set out in the following sections, where all tests are described in detail.

To determine the potential for use in soil bio-engineering, we tested the rooting ability of stem cuttings in the field, as this was not considered in the above mentioned studies. The ability of Spanish Broom cuttings to root was studied in order to assess the potential for agamic propagation, as well as to understand the root architecture and the resulting Root Area Ratio (RAR).

\section{Study area}

The study was conducted in the area of San Casciano Val di Pesa (Florence), in the heart of Tuscany (Italy), just a few $\mathrm{km}$ south of Florence (Fig. 1).The field site was located in the Gentilino area on a slope belonging to the Municipality of San Casciano. The hill slope has a 50\% inclination and a southeastern exposure. The slope where the tests were performed is artificial, being made of landfill (Fig. 1). In order to control and/or avoid erosion and shallow landslides, Spanish Broom was transplanted upon completion of the artificial

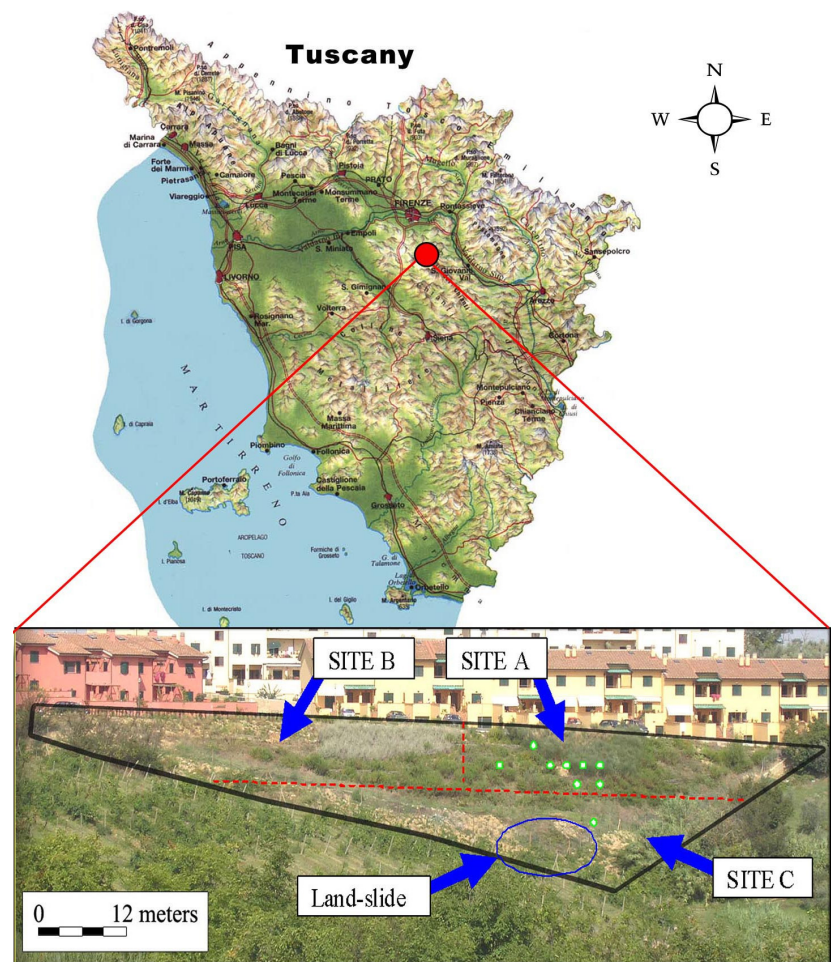

Fig. 1. Localization of the study area: Gentilino experimental sites (A, B and C), the sampling points and the site of a recent landslide. Gabbiola and Spedaletto sites are ex-agricultural areas colonised by natural shrubs $300 \mathrm{~m}$ away from Gentilino area.

slope. The plants had grown in a local nursery and had been transplanted with their root balls, when the slope was being restored. The plantation is square with sides about $50 \mathrm{~cm}$ long. Eleven plants were sampled, eight from the artificial slope and three from spontaneously-growing plants in nearby areas (Gabbiola and Spedaletto sites are ex-agricultural areas colonised by natural shrubs $300 \mathrm{~m}$ away from Gentilino area), Fig. 1 and Table 3. All the plants (from the nursery and the spontaneous ones) were of the same age, about seven years old.

In 2007 a small landslide occurred at the foot of the slope in an area without vegetation. Fig. 2a shows the geometry of the landslide; the scarp was about $120 \mathrm{~cm}$ high for a front lenght of 6-7 m.

\section{Hydrology}

The climate of the study area is Mediterranean (Köppen classification). Data for the rainfall as well as the maximum, average and minimum temperatures (http://agrometeo.arsia. toscana.it/) gives the daily average potential evapotranspiration $T p$, the rainfall frequency $\lambda_{0}$, and the average rain events intensity $\alpha$ (Table 2). Rainfall Intensity-Duration-Frequency data gives the curve equation $I=21.65 \operatorname{Tr}^{0,18} D^{(0,21-1)}$, where $I=$ rainfall intensity $[\mathrm{mm} / \mathrm{h}], T r=$ return time interval 
Table 2. Daily rainfall data parameters at Sambuca and Ponte a Moriano measured by rainfall gauges: $T p=$ potential evapotranspiration, $\lambda=$ rainfall frequency, $\alpha=$ average rainfall intensity.

\begin{tabular}{llllll}
\hline & \multicolumn{5}{c}{ Summary climate parameters } \\
\cline { 3 - 4 } Gauge & \begin{tabular}{l} 
Experimental \\
\cline { 3 - 4 }
\end{tabular} & $\begin{array}{l}T p \\
{[\mathrm{~mm} / \mathrm{d}]}\end{array}$ & $\begin{array}{l}\lambda \\
{[\text { event/d] }]}\end{array}$ & $\begin{array}{l}\alpha \\
{[\mathrm{mm} / \mathrm{event}]}\end{array}$ & $\begin{array}{l}\text { Time series } \\
\text { data }\end{array}$ \\
\hline $\begin{array}{l}\text { Sambuca } \\
1680260 \mathrm{E}\end{array}$ & $\begin{array}{l}\text { San Casciano } \\
\text { in Val di Pesa } \\
4829130 \mathrm{~N}\end{array}$ & 2.189 & 0.374 & 5.284 & 2001-2006 \\
\hline
\end{tabular}

Table 3. Soil sample characteristics.

\begin{tabular}{lrrrrl}
\hline & Clay & Silt & Sand & Porosity & $\begin{array}{l}\text { Classification } \\
\text { USDA }\end{array}$ \\
\hline Site A & & & & & \\
Site $\mathrm{A}_{\alpha}$ & $44.0 \%$ & $46.4 \%$ & $9.6 \%$ & $56.0 \%$ & Silty Clay \\
Site $\mathrm{A}_{\beta}$ & $18.3 \%$ & $48.5 \%$ & $33.2 \%$ & $38.7 \%$ & Loam \\
Site $\mathrm{A}_{\rho}$ & $31.1 \%$ & $56.8 \%$ & $12.1 \%$ & $35.5 \%$ & Silty Clay Loam \\
Site $\mathrm{A}_{\phi}$ & $29.6 \%$ & $58.4 \%$ & $12.0 \%$ & $39.3 \%$ & Silty Clay Loam \\
Site Bs & $49.9 \%$ & $42.2 \%$ & $7.9 \%$ & $57.0 \%$ & Silty Clay \\
Site Bp & $53.6 \%$ & $38.5 \%$ & $7.9 \%$ & $60.0 \%$ & Silty Clay Loam \\
Site Cs & $14.9 \%$ & $52.8 \%$ & $32.3 \%$ & $30.7 \%$ & Silt Loam \\
Site Cp & $10.7 \%$ & $35.5 \%$ & $53.8 \%$ & $27.3 \%$ & Loam \\
Site Cplandslide & $28.7 \%$ & $34.2 \%$ & $37.2 \%$ & $42.0 \%$ & Clay Loam \\
Site Cs landslide & $49.2 \%$ & $37.2 \%$ & $13.6 \%$ & $49.0 \%$ & Clay \\
Gabbiola Bs & $29.1 \%$ & $49.0 \%$ & $21.9 \%$ & $24.5 \%$ & Clay Loam \\
Gabbiola Bp & $31.0 \%$ & $47.5 \%$ & $21.5 \%$ & $20.6 \%$ & Silty Clay Loam \\
Gabbiola A & $31.1 \%$ & $48.7 \%$ & $20.2 \%$ & $23.3 \%$ & Silty Clay Loam \\
Spedaletto & $30.4 \%$ & $48.4 \%$ & $21.2 \%$ & $24.5 \%$ & Silty Clay Loam \\
\hline
\end{tabular}

[years], $D=$ rainfall duration [h], and the runoff coefficient value ranges from 0.52 to 0.66 according to previous studies on Flood Regionalization (Regione Toscana, 2007).

\section{Soils}

Analysis of the soil began by obtaining three soil profiles. To classify the soil, geotechnical tests were carried out according to the standards of the AASHTO system (adopted in Italy by the CNR-UNI 10006 norm). The percentages in the fine part of the soil were determined with a soil hydrometer. With regard to the limits of Attemberg, the Casagrande bowl was used. In order to determine the friction angle, three soil shear drained-saturated CD tests were carried out with loads of 50, 100, 150 and $200 \mathrm{Kpa}$.

\section{Root distribution and estimation of Root Area Ratio (RAR)}

The spatial distribution of the Spanish Broom roots was evaluated digging out by hand, starting from the collar, removing the soil and exposing the root system. As far as the horizontal distribution is concerned, the plants were planted in the artificial slope with a square layout with sides about $50 \mathrm{~cm}$ long

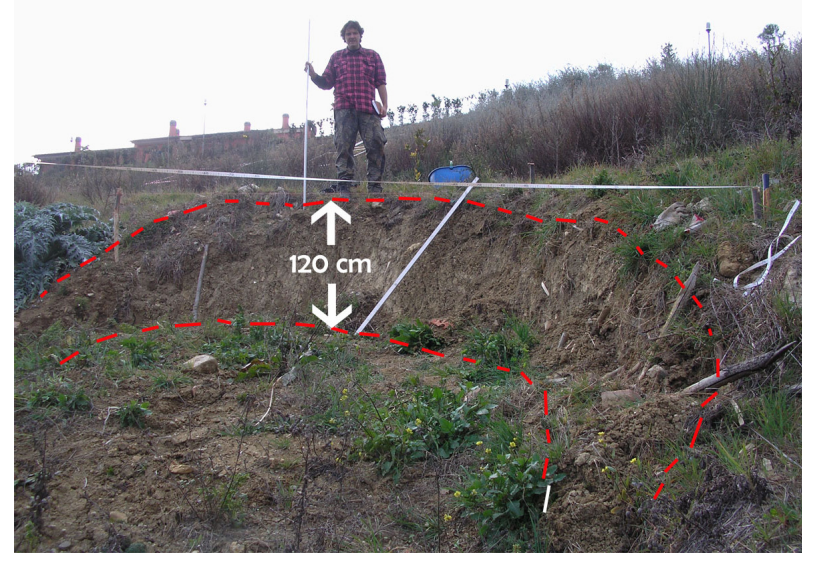

Fig. 2a. Land slide occurred in December 2007 in an unvegetated part of the experimental slope.

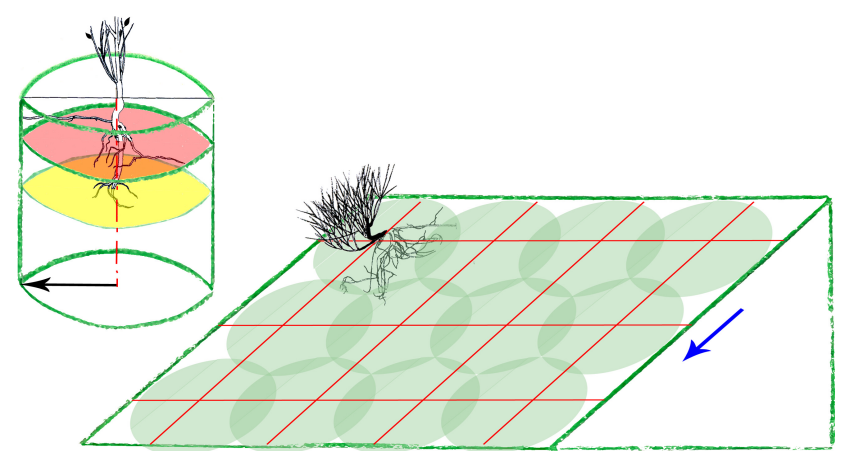

Fig. 2b. Experimental slope layout of transplanted plants: square sides about $50 \mathrm{~cm}$ and horizontal section at $5 \mathrm{~cm}$ step. The mean soil diameter explored by the root system slightly superimposes (adapted from Chiatante et al., 2003b).

(Fig. 2b): the mean soil diameter explored by the root system slightly superimposes. As far as the vertical distribution is concerned, for each plant (transplanted and spontaneous) we measured the number and the diameter of those roots going through a horizontal section for each depth level $(5 \mathrm{~cm}$ intervals). Furthermore we measured the maximum distance reached by the roots with reference to the collar.

There are several methods that can be used to assess the Root Area Ratio, i.e. ratio between root area and rooted-soil area (RAR). One is known as core-break sampling (Schmid and Kadza, 2002). Another consists in counting roots using a profile trench (Bohm, 1979). A further method involves extracting the plant from the soil without damaging its roots; this can be done by using jets of water (Tosi, 2007). In the case of the trench profile, roots can be measured either directly or from a photograph (Vogt and Persson, 1991; Bischetti et al., 2005). In our case the excavated plants were brought to our laboratory while they were still fresh. The rooted area (Ar) for each depth level was calculated by summing the areas of the single cross sections roots. The RAR of 
all samples was calculated with the direct method assuming a constant radius (specific for each plant) equal to the maximum distance reached by the roots with reference to the col$\operatorname{lar}$ (Fig. 2b). Also the indirect method was used in the case of four plants in order to compare the two methods. As far as the indirect method is concerned, after excavating the root system, we interposed it by a grid of known dimensions, and a photo was taken, displaying the roots in the position in which they had been in the soil. Afterwards we rectified the image in order to avoid image distortion errors and we counted and measured the diameter of the roots using AutoCAD ${ }^{\text {tm }}$ (Dani and Preti, 2007, Fig. 3).

The formula we used to estimate RAR was the following:

$\operatorname{RAR}(z)=\sum_{i=1}^{m} \frac{\operatorname{Ar}(z)_{i}}{\operatorname{As}(z)} \cong \sum_{i=1}^{m} \frac{d(z)_{i}^{2}}{D_{s}^{2}}$

where:

$\operatorname{Ar}(z)_{i}=$ area of the i-th root;

As $(z)=$ rooted-soil area;

$z=$ depth;

$d(z)_{i}=$ diameter of the i-th root;

$D_{s}=$ measured largest soil diameter explored by the root system (cylindrical rooted volume is assumed);

$m=$ number of roots at $z$ depth.

In order to upscale the RAR to the stand scale, we calculated the average for the eight analysed plants.

\section{Lab tensile tests on roots}

Tensile strength tests were performed at the Laboratories of Wood Technology, Department of Forest Environmental Sciences and Technologies, University of Florence. Two machines were used for the tests: the "Remo-Mat" and "Amsler". The Remo-Mat is a prototype machine, engineered and built in the same laboratory for the tensile testing of small wooden specimens, with digital control and recording systems. The Amsler Universal Testing Machine is an hydraulic testing machine, having a $40 \mathrm{kN}$ maximum load, that was improved by installing a load cell and transducers. It is connected to a computer for digital data acquisition. Measurements for assessing the tensile force value of Spanish Broom were performed on 98 samples whose diameters ranged from 0.65 to $9.9 \mathrm{~mm}$ (including root bark). Tests were performed about one hour after removing the root samples from the field and storing them in moist conditions. There was no need for preservation in alcohol, as there was no chance for withering to occur. The small diameter roots $(d<2.5 \mathrm{~mm})$ were tested with the Remo-Mat, while the bigger ones were tested on the Amsler machine. Breaking of specimens was achieved in about $90 \mathrm{~s}$ in the Amsler machine, while breaking time ranged from 150 to $300 \mathrm{~s}$ on the Remo-Mat, due to the different method of control, the first being analogue while the second, digital. The two testing machines have similar cylindrical anchoring systems.

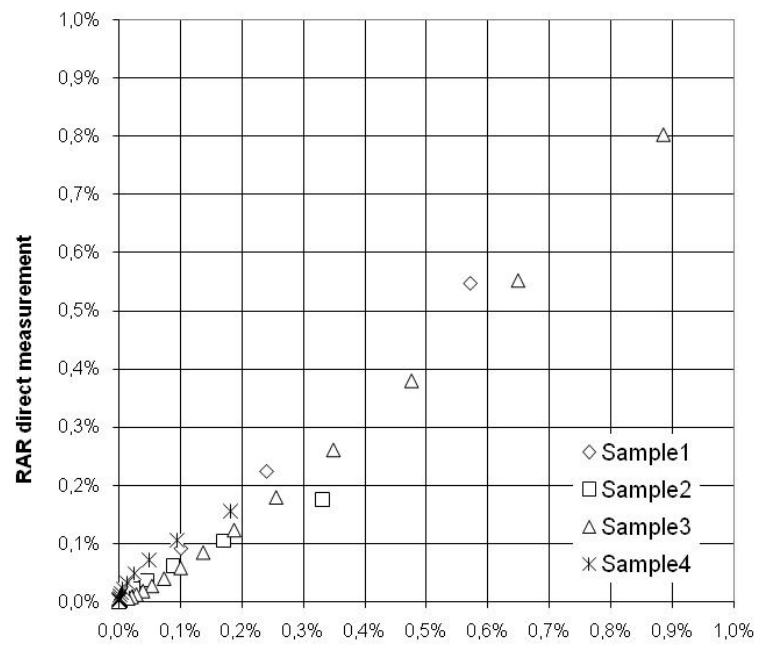

RAR indirect measurement (orthophoto)

Fig. 3. RAR estimation (four Spanish Broom specimens) using the direct and indirect method.

After testing, some of the specimens were used to determine moisture content (MC). The weight of the specimens was measured; then the roots were put in a dry oven at a temperature of $103^{\circ} \mathrm{C}\left( \pm 2^{\circ} \mathrm{C}\right)$. The measurements, taken $24 \mathrm{~h}$ later, were used to determine moisture content with reference to the dry weight $(\mathrm{MC}=(M u-M o) / M o$ where $M u$ is the weight at the moment of the test while $M o$ is the dry weight).

\section{Root cohesion}

The values of the additional soil cohesion $(C v)$ were calculated with the following formula, according to the $\mathrm{Wu}$ (1976) and Waldron (1977) model:

$C v(z)=K \sum_{j=1}^{n} \operatorname{Tr}_{j}(\operatorname{RAR}(z))$

where:

$T r_{j}=$ tensile strength of the $\mathrm{j}$-th diameter class;

$n=$ number of diameter classes at $z$ depth.

One of the most important assumption made in the Eq. (2) is that all of the roots break simultaneously and at their peak strength. According to Pollen and Simon (2005), Preti (2006), De Baets et al. (2008), Preti et al. (2009), Schwarz et al. (2009), the Wu and Waldron model overestimates (more than 200\%) root cohesion values (by putting only $K=1.2$ as standard, root cohesion values could be considered maximum values). $C v$ was calculated for each cross section depth, applying to every root the tensile strength value $\mathrm{Tr}$ referred to its diameter (Fig. 8). In doing so, the contribution of each root was taken into account. 


\section{Factor of safety}

In order to consider the effect of vegetation on stability, we adopted the infinite slope method (Coppin and Richards, 1990; Schimdt, 2001), in the following form (Preti, 2006):

$F_{s}=\frac{\left(c^{\prime}+c_{v}^{\prime}\right)}{\left(\gamma_{\mathrm{sat}} \cdot z \cdot \cos \beta+W_{v}\right) \cdot \sin \beta}+\frac{\left(\gamma z \cdot \cos \beta+W_{v}\right)}{\left(\gamma_{\mathrm{sat}} \cdot z \cdot \cos \beta+W_{v}\right)} \cdot \frac{\tan \phi}{\tan \beta}$

where:

$F s=$ Factor of safety;

$c^{\prime}=$ soil cohesion $[\mathrm{kPa}]$

$c_{v}^{\prime}=$ root cohesion $[\mathrm{kPa}]$;

$z=$ vertical depth of the failure plane $[\mathrm{m}]$;

$\beta=$ slope angle $\left[{ }^{\circ}\right]$;

$\phi^{\prime}=$ soil friction angle $\left[{ }^{\circ}\right]$;

$\gamma=\gamma_{\text {sat }}-\gamma_{w}$ "submerged" bulk unit weight $\left[\mathrm{kN} / \mathrm{m}^{3}\right]$;

$\gamma_{\text {sat }}=$ saturated bulk unit weight $\left[\mathrm{kN} / \mathrm{m}^{3}\right]$;

$W_{v}=$ overload due to vegetation $[\mathrm{kPa}]$.

In the following, the Fs was calculated under the measured conditions: saturated bulk unit weight $\left[\mathrm{kN} / \mathrm{m}^{3}\right]$ $\gamma_{\mathrm{sat}}=20 \mathrm{kN} \mathrm{m}^{-3} \quad$ (porosity 0.42 ), water unit weight $\gamma_{w}=9.8 \mathrm{kN} \mathrm{m}^{-3}$, slope angle $\beta=26.5^{\circ}$, soil friction angle $\phi^{\prime}=20^{\circ}$, soil cohesion $=1 \mathrm{kPa}$. The surcharge on the soil slope owing to the presence of plants $(W v)$ was calculated on the basis of both the average weight of the Spanish Broom transplanted and spontaneous plants and their density $(50 \times 50 \mathrm{~cm})$, giving a value of $20-40 \mathrm{~kg} / \mathrm{mq}$, which is equivalent to $0.196-0.4 \mathrm{kPa}$, respectively.

$F s$ was calculated for every $5 \mathrm{~cm}$ soil layer, considering the RAR at the stand scale and the value of $\operatorname{Tr}$ referred to the diameter of every root (from the equation in Fig. 8) which crosses the horizontal plane at that given depth, and considering the deriving $C v$.

\section{Spanish Broom propagation}

Normally Spanish Broom propagation occurs by seed. Sowing takes place in spring in seedbeds, and the seedlings are later transplanted to their permanent locations. However, our interest lays in investigating agamic propagation in the field and resulting root system development. A total of 360 cuttings taken from existing plants in the study area were planted at four different times: August, October, November 2007 and February 2008 (Table 4) to ascertain the best rooting period for stem cuttings (Cervelli et al., 2004). For purposes of comparison, 360 new root-ball specimens were planted in the same area where Spanish Broom had been transplanted seven years previously (Fig. 1).

The synthetic chemical products used for inducing rooting were indolbutirric acid (IBA) and naftalenacetic acid (NAA), although other auxins can be used. They were the most effective with regard to obtaining adventitious roots on stem cuttings. These chemical products are available either in powder or liquid form, and the latter can be diluted in water to the appropriate concentration. Woody species that take
Table 4. Number of planted stem cuttings for different experimental conditions.

\begin{tabular}{llllllll}
\hline & \multicolumn{2}{c}{ Site A } & \multicolumn{2}{c}{ Site B } & \multicolumn{2}{c}{ Flowerpot } & \\
& with & no & with & no & with & no & \\
& NAA & NAA & NAA & no NAA & NAA & NAA & Total \\
\hline Aug 2007 & 20 & 20 & 20 & 20 & 10 & 10 & 100 \\
Oct 2007 & 20 & 20 & 20 & 20 & 10 & 10 & 100 \\
Nov 2007 & 20 & 20 & 20 & 20 & - & - & 80 \\
Feb 2008 & 20 & 20 & 20 & 20 & - & - & 80 \\
Total & 80 & 80 & 80 & 80 & 20 & 20 & 360 \\
\hline
\end{tabular}

root with greater difficulty must be treated with products at high hormonal concentrations whereas species that are tender, herbaceous and take root easily must be treated with less concentrated preparations. The cut at the base of the stem cutting must be fresh: i.e. it must be made just before dipping the cutting into the powder in order for the latter to adhere. The powder that sticks to the stem cuttings after they are lightly pressed onto the product is sufficient. Dampening the base of the stem cuttings beforehand in order to improve adherence can be useful (Hartmann et al., 2002). Some stem cuttings were treated with root-stimulating substances (NAA, containing alpha-naphthyl acetic acid as the base).

Two sites of the study area were singled out and roped off (sites A and B in Fig. 1). Site A was next to where the root-ball Spanish Broom plants were planted; site B was $30 \mathrm{~m}$ away on the same contour line, isolated from the other Spanish Broom plants. This distribution was chosen in order to verify a possible correlation between the soil that was already colonized by Bradyrhizobium spp., bacteria and Glomus fungi and the rooting ability only for the first test) (Quatrini et al., 2002). In turn, the two sites were divided into two sections: stem cuttings with or without use of plant hormone for rooting. The plant hormone we used contained alphanaphthyl acetic acid (NAA), a very common exogenous synthetic phytoregulator. The stem cuttings used for the first test were $20-25 \mathrm{~cm}$ long (herbaceous cuttings), and those for the subsequent tests were $60-70 \mathrm{~cm}$ long (semi-woody cuttings). In this case cuttings were planted at $20-30 \mathrm{~cm}$ depth. At the time of planting, all sites were irrigated with about 151 of water each. A second irrigation was performed two days later, again with 151 of water, and a third one 10 days after planting. Forty stem cuttings were planted on each site, 20 of which were treated with hormone (left side, if looking at the slope from below) and the other 20 untreated (right side). Another 20 stem cuttings were planted in pots, 10 of which were treated with hormones and the other 10 untreated. The soil used in the pots was from the testing site. The purpose of planting in pots was to have more control over the stem cuttings by using irrigation (Table 4 ). 


\section{Results}

\section{Soil analysis}

Within the soil profile only one horizon B was observed (up to $50 \mathrm{~cm}$ ), overlapped by a thin layer of undecomposed organic matter. When wet the soil was very sticky, which is typical of clay-silty soils. The colour was light brown, with many gray streaks (clay) and some tending more towards red (sandier). The distribution of rocks of various sizes (some measuring more than $10 \mathrm{~cm}$ ) along the slope was heterogeneous. Fragments of bricks and other aggregates were found in the soil, along with other construction-site-wastes. According to USCS nomenclature, the soil generally has a texture defined as ML. The soil characteristics are shown in Table 3. The liquid limit and the plastic limit were $48 \%$ and $28 \%$, respectively. The activity index was 0.59 (inactive clays). Friction angle resulted about $20^{\circ}$ and a cohesion ranging from 0 to $0.2 \mathrm{Kpa}$. Excavated soil was very clayey, with little skeleton, and when placed under light pressure, it crumbled to a minimum particle size of 4 to $10 \mathrm{~mm}$. This size depended on the amount of moisture present.

\section{Root distribution analysis}

The average root number of transplanted and spontaneous plants at the various depths (Fig. 4), shows slight differences in the first $10 \mathrm{~cm}$ and we find a high Standard Deviation in the superficial soil layers. The distribution of the roots was obtained by counting the number of roots in the $1 \mathrm{~mm}$ diameter classes and by determining the values for each vertical soil level explored (Fig. 5a). This graph shows only transplanted plants, which are more interesting as they form a continuous vegetated slope, suited to compare the cohesion data to a stand scale. Figure $5 \mathrm{~b}$ shows the comparison between average root diameter of transplanted and spontaneous Spanish Broom plants. Considering the percentage number of roots at different depths, it is noted that (Fig. 6) at a depth of $20 \mathrm{~cm}$ we find $90 \%$ of transplanted plants roots and $65 \%$ of spontaneous plants roots. At a depth of $40 \mathrm{~cm}$ there are almost all the roots of all the plants, with the exception of the spontaneous plants top-roots, representing only $10 \%$.

The large root at shallow depths (from 0.0 to $0.10 \mathrm{~m}$ ) influences the value of the root mean diameter, and for larger depths, the root system of spontaneous plants branches off and the root mean diameter remains quite constant up to $0.7 \mathrm{~m}$.

For transplanted plants the maximum distance reached by a root with reference to the collar is about $50 \mathrm{~cm}$, while for the spontaneous plants is about $60 \mathrm{~cm}$. Table 5 shows the values of the maximum, minimum, mean, standard deviation and Coefficient of Variation (CV). It can be observed that $\mathrm{CV}$ values are almost similar in spontaneous and transplanted plants. The maximum depth of the main root was $70 \mathrm{~cm}$ for spontaneous plants, while about $40 \mathrm{~cm}$ for trans-

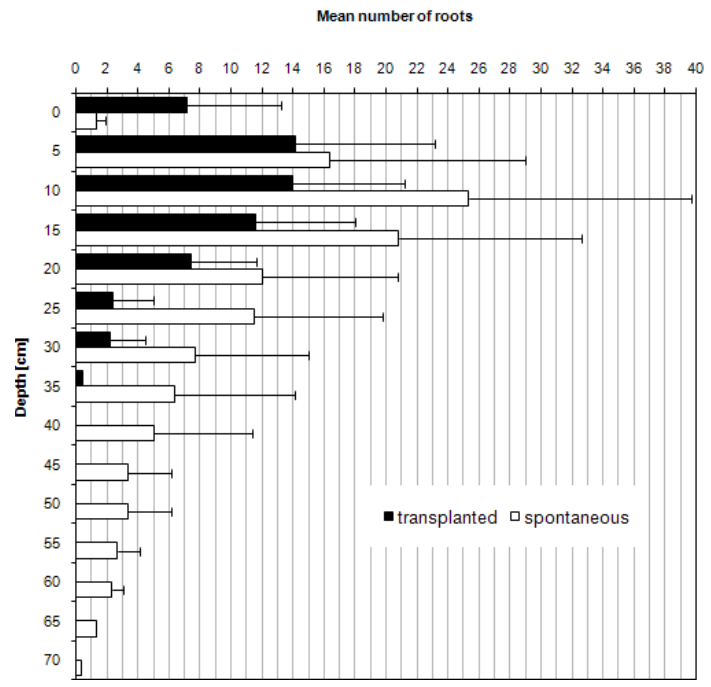

Fig. 4. Average root number with SD bars versus depth of transplanted and spontaneous Spanish Broom plants. All plants are about seven years old.

Table 5. Root diameter of transplanted and natural plants.

\begin{tabular}{lcc}
\hline Root diameter & transplanted & spontaneous \\
\hline Max $[\mathrm{mm}]$ & 33.1 & 34.0 \\
Min $[\mathrm{mm}]$ & 0.3 & 0.5 \\
SD & 4.6 & 3.7 \\
Mean $[\mathrm{mm}]$ & 4.1 & 3.3 \\
CV & 1.125 & 1.145 \\
\hline
\end{tabular}

planted plants. The trend of the average RAR of Spanish Broom for each depth can be described as an exponential curve, as shown in Fig. 7.

\section{Tensile strength tests}

The regression curves obtained for tensile force $t r$ versus diameter (Schmidt el al., 2001) were as follows (Fig. 8): $t r=0.0203 d^{2}+0.0062 d R^{2}=0.94 \mathrm{SD}=0.287$ for all 98 samples, $t r=0.0233 d^{2}+0.0034 d R^{2}=0.93 \mathrm{SD}=0.334$ for the data obtained by the Amsler, and $t r=-0.0176 d^{2}+$ $0.0241 d R^{2}=0.62 \mathrm{SD}=0.027$ for those obtained by RemoMat.

Each machine works on different diametric ranges with an overlap of $1.3 \mathrm{~mm}$. The minimum diameter was $0.65 \mathrm{~mm}$ and the maximum $9.9 \mathrm{~mm}$.

The roots unit tensile strength $\operatorname{Tr}$ is not constant but instead increases as diameter decreases. The minimum, maximum and mean values of the unit tensile strength resulted 9.7, 65 and $31.7 \mathrm{MPa}$, respectively. The data indicate the same general tendency, which is explained by the power law model and has been widely reported in the literature for 


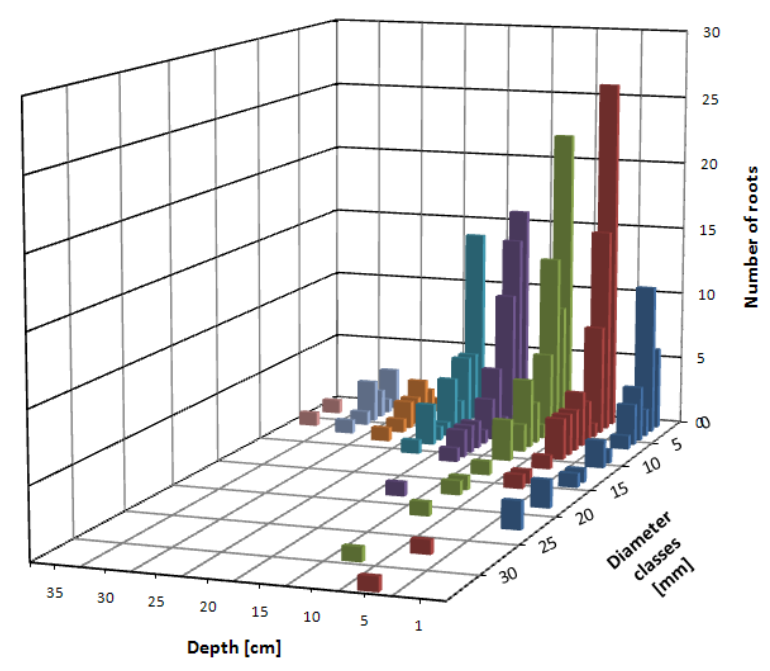

Fig. 5a. Vertical distribution of transplanted plant root number: root diameter classes per every cross section depth $(5 \mathrm{~cm}$ step).

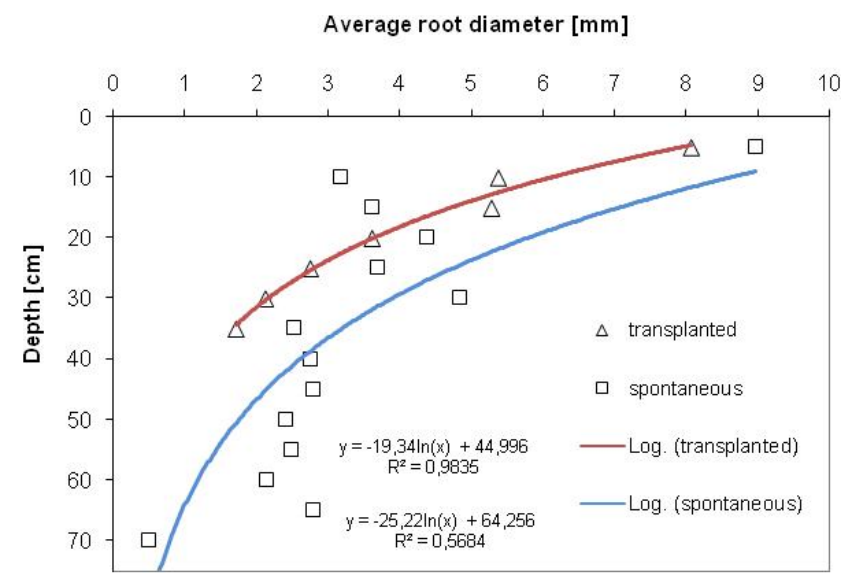

Fig. 5b. Average root diameter of transplanted and spontaneous Spanish Broom plants.

different species (e.g. Mattia et al., 2005; Bischetti et al., 2005; Tosi, 2007; De Baets et al., 2008). In some cases the breakage measurements for the wooden root and the bark were similar. The tensile strength was calculated using the maximum value. In some thick roots breakage occurred away from the centre of the specimen, inside the clamp.

The roots tested immediately after extraction from the field had a high moisture content, above the fibre saturation point (conventionally stated as $30 \%$ of dry weight in wood). The mean value of the moisture content (MC) of the specimen, determined in relation to the dry weight, was about $40 \%$.

\section{Stability and hydrological analysis}

By correlating the measured tensile strength with measured RAR (Fig. 7), the additional cohesion due to the presence of

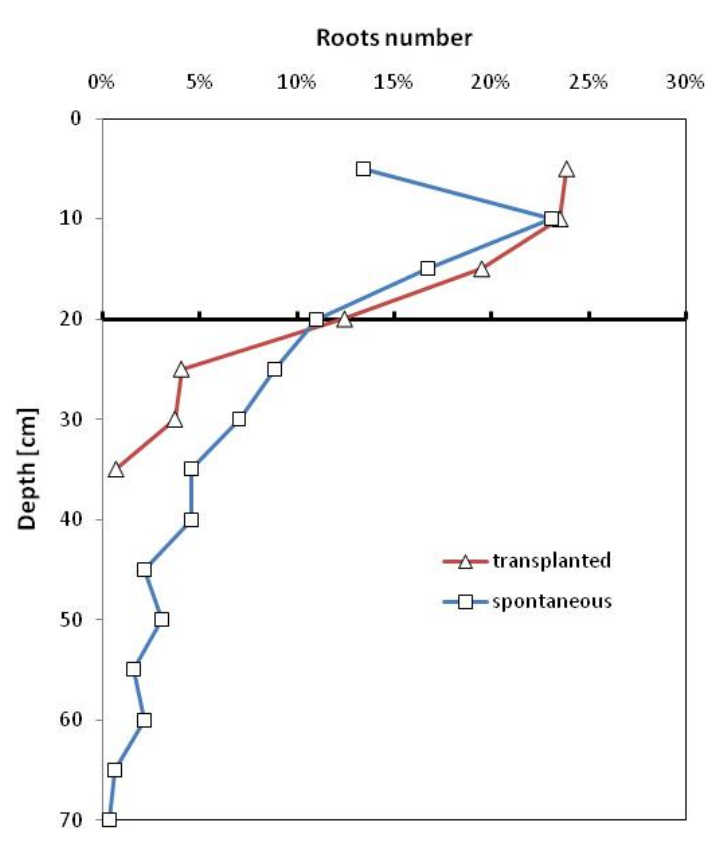

Fig. 6. Percentage roots distribution: at a depth of 20 there are $90 \%$ of transplanted plants roots and $65 \%$ of natural plants; at $40 \mathrm{~cm}$ there are respectively $100 \%$ and $90 \%$ of roots.

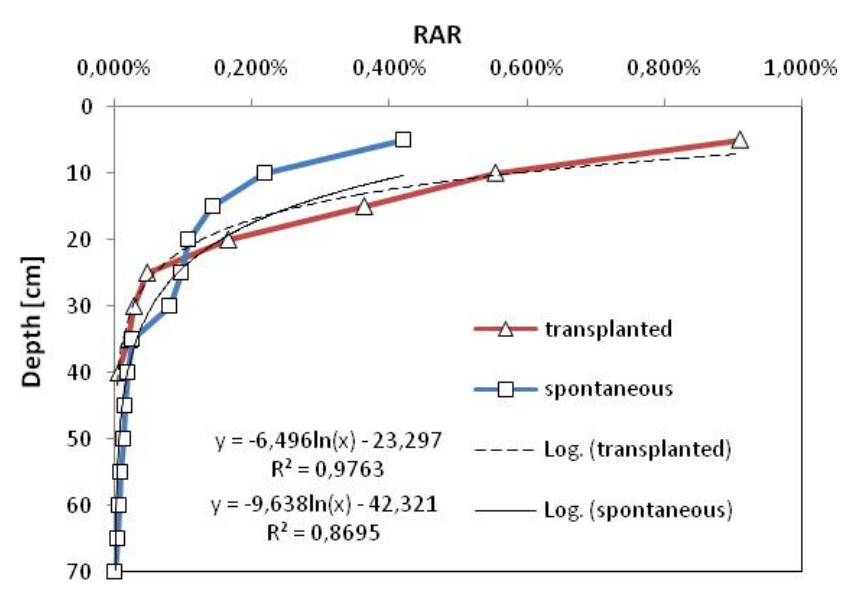

Fig. 7. RAR versus depth of transplanted and spontaneous Spanish Broom plants.

roots in the soil is obtained according to the $\mathrm{Wu}$ and Waldron model. The $C v$ was estimated taking into account the tensile strength value obtained from regression curve (Fig. 8) for each root at the horizontal cross section of soil. The variation in $C v$ depending on depth is shown in Fig. 9.

$F s$ on saturated soil at various depths is shown in Fig. 10 for different scenarios: unvegetated soil, transplanted stand and natural slope. The presence of roots significantly increases the stability factor, with a maximum value at that depth which includes $90 \%$ of roots, both for transplanted and spontaneous plants. The $F s$ of the unvegetated slope 


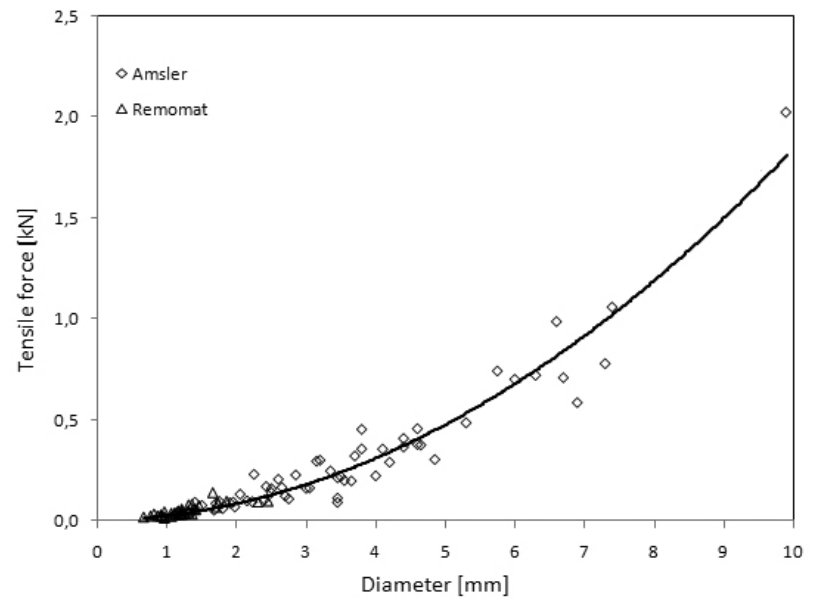

\begin{tabular}{|c|c|c|c|c|c|}
\hline & Samples & Diameter & $\begin{array}{c}\text { Tr [MPa] } \\
\varnothing 1 \mathrm{~mm}\end{array}$ & Exp & $\begin{array}{c}\text { Tr [MPa] } \\
\text { Average }\end{array}$ \\
\hline$(1)$ & 98 & $0.70-9.90$ & 37.7 & $-0,306$ & 31,9 \\
\hline$(2)$ & 48 & $0.65-9.35$ & 36.6 & -0.341 & 30,3 \\
\hline$(3)$ & 24 & $0.44-2.68$ & 56.4 & -0.239 & 44,6 \\
\hline$(4)$ & - & - & - & - & 17,0 \\
\hline
\end{tabular}

Fig. 8. Tensile force $[\mathrm{kN}] t r$ versus root diameter of Spanish Broom. The line shows the second order polynomial regression curves fitted to the experimental data: $t r=0.0203 d^{2}+$ $0.0062 d R^{2}=0.94$. The regression equation of tensile strength [MPa] $\operatorname{Tr}$ versus root diameter [mm] of Spanish Broom curve is (1) $T r=37.605 d^{-0.306} R^{2}=0.29$. Comparison between literature data: (2) Tosi (2007); (3) Laranci et al. (2004); (4) Norris and Greenwood (2003).

is 1 with a slope of about $50 \%$ at a depth of $20 \mathrm{~cm}$. This value increases at $35 \mathrm{~cm}$ with transplanted plants and reaches the maximum value of $65 \mathrm{~cm}$ with spontaneous plants, which have a deeper tap-root.

Considering the above-mentioned rainfall-duration curve $\left(h=a^{\prime} \operatorname{Tr}^{m} D^{n}\right)$ and the saturated landslide depth, the return time $T r$ of the hydrological instability threshold can be calculated. We obtained an $\operatorname{Tr} \sim 10$ years for a rainfall duration of $24 \mathrm{~h}$ by considering the known runoff coefficient value and the estimated upslope contributing area (connection with the urbanized area in Fig. 1 with concentration coefficient equal to 10$)$.

\section{Spanish Broom propagation}

Surveys on vegetative conditions were conducted in February, March and June. Almost two years after planting, all the root-ball plants had rooted, $93.4 \%$ of stem cuttings without hormone treatment had died, and $92.3 \%$ of stem cuttings with hormone treatment had died. The survival rate of the stem cuttings planted in pots was 5\%. As shown in Fig. 11, roots (about $20 \mathrm{~cm}$ long) developed only from the deeper regions of the stem cutting (October 2007 planting).

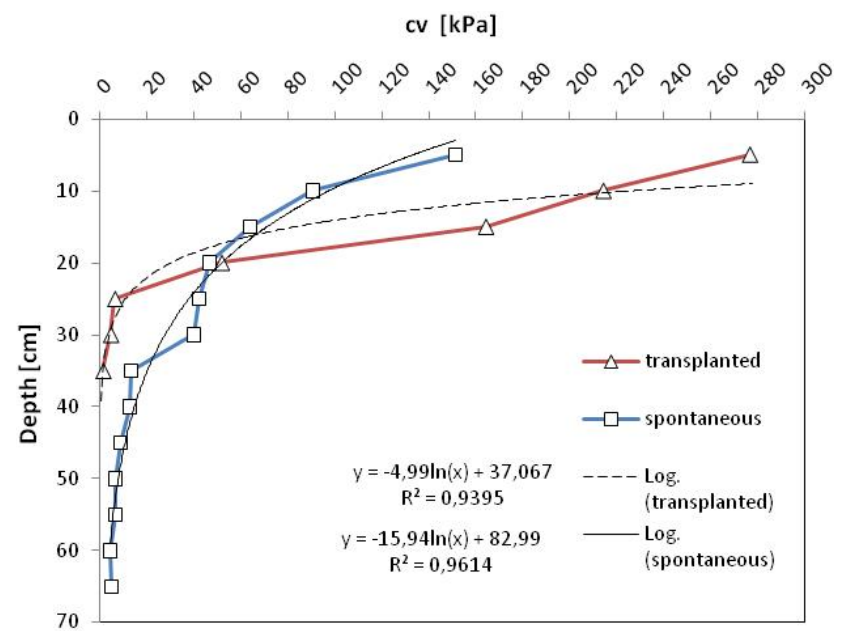

Fig. 9. Root cohesion $C v$ versus depth of transplanted, spontaneous and all Spanish Broom plants: la RAR considerata nel calcolo è quella riferita a un metro quadrato. Per ogni singola radice è stato applicato il valore di $\operatorname{Tr}$ riferito al suo diametro, come da Fig. 8 .

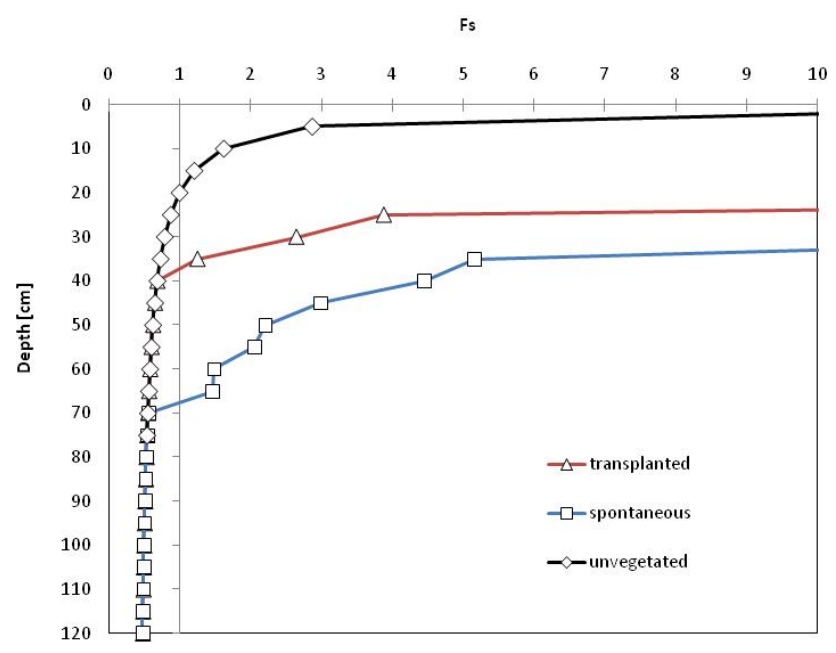

Fig. 10. Factor of safety $(F s)$ versus depth in unvegetated soil, transplanted stand or natural slope under the following conditions: saturated bulk unit weight $\left[\mathrm{kN} / \mathrm{m}^{-3}\right], \gamma_{\mathrm{sat}}=20 \mathrm{kN} \mathrm{m}^{-3}$, water unit weight $\gamma w=9.8 \mathrm{kN} \mathrm{m}^{-3}$, slope angle $\beta=26.5^{\circ}$, soil friction angle $\phi^{\prime}=20^{\circ}$, soil cohesion $=1 \mathrm{kPa}$, surcharge $W v=0-0.196-0.4 \mathrm{kPa}$, respectively. $C v(z)$ as in Figs. 9 and 5.

\section{Discussion}

\section{Root distribution}

The analyzed root systems did not show substantial differences in their architecture: they have always a tap-root and a high concentration of roots in the first $10 \mathrm{~cm}$ of soil. There are however some differences between the growth of spontaneous and transplanted plants, as shown in the following paragraphs. The root distribution of the transplanted plants 


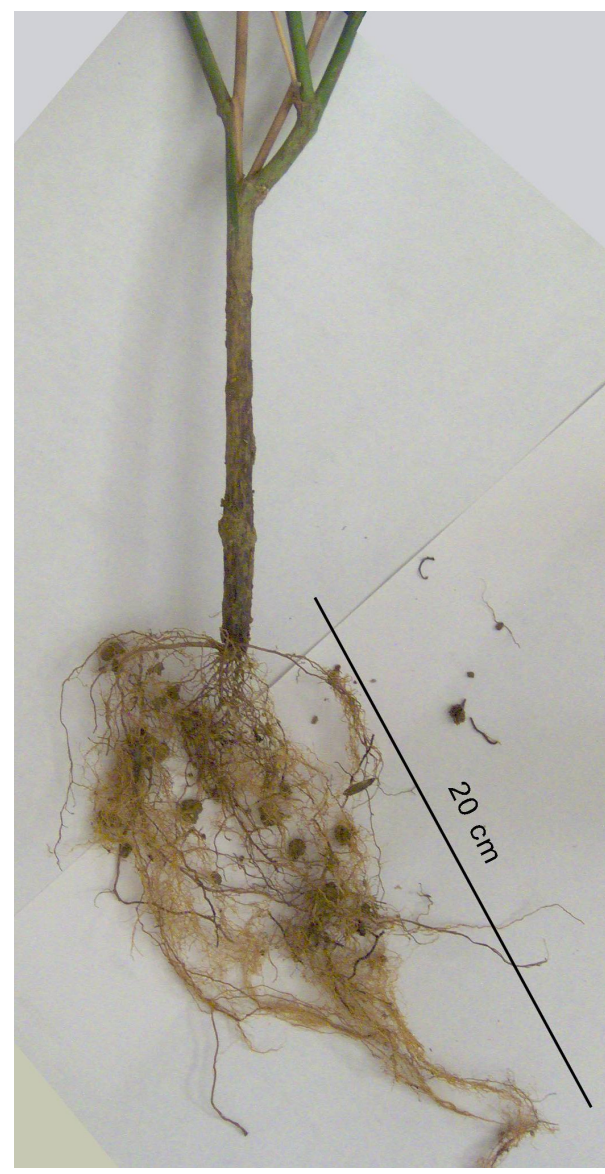

Fig. 11. Specimen of rooted cutting of Spanish Broom 1 year after plantation.

(Figs. 5, 6, 7, and 8) could be due to plant origin and growth and soil condition (in pot, nursery and natural soils). Container grown seedlings often have a limited root system, with lateral roots spiralling around the container and bare-root seedlings are often deformed during transplanting and roots damaged or bent (Lindström and Rune, 1999; Nörr, 2003). The soil diameter explored by the root system $D_{s}$ is less large for transplanted plants and consequently the average RAR displays a similar trend (Fig. 7). It can be noticed that transplanted plants are effective for slope stabilization at soil depth up to $40 \mathrm{~cm}$, while natural plants up to $70 \mathrm{~cm}$. Transplanted plants have a high concentration of roots in the first centimeters of soil as shown by the very high number of roots (Figs. 4, 5a, and 6) and RAR (Fig. 7). The average root diameter at various depths is similar for transplanted and spontaneous plants as shown in Fig. 5b. The percentage distribution of the roots is almost uniform on the whole profile and could be the consequence of the growing conditions mentioned above. Considering that the age of the transplanted and of the spontaneous plants is almost the same, the provenance from the nursery, and consequently the growth in the pot during the first years, could have negatively affected the roots distribution. The. differences in roots distribution are destined to decrease in time. Roots number variability (Fig. 4) decreases as depth increases. At depths between 0 and $40 \mathrm{~cm}$ the root system branches off, while at depths exceeding $40 \mathrm{~cm}$, it is basically only the tap-root that contributes to the RAR. In transplanted plants the development of the tap-root is limited, but there are more roots on the surface.

The difference between soils (Gentilino clay soils and natural slope less clayey soil) resulted only in a lower average rooting depth at Gentilino (Schenk and Jackson, 2002a, b; Laio et al., 2006; Preti et al., 2009).

Our average diameters values are consistent with the reported by Tosi (2007), who found an average diameter of $8.8 \pm 6.8 \mathrm{~mm}$ Standard Error at $5 \mathrm{~cm}$ of depth.

The photogrammetric method (indirect method) used to assess RAR was comparable with the direct type of measurement (Fig. 3) and offers a number of advantages: measurements can be taken at a different time from when the picture is taken; therefore it is not necessary to take steps to prevent the plants from drying out.

\section{Tensile strength tests}

Figure 8 shows that the tensile force values measured in the laboratory (in our study, 98 samples after having excluded values from anomalous samples, $R^{2}=0.94$ ) are consistent with Tosi's curve (2007), as far as lab is concerned (48 samples, $R^{2}=0.96$ ) The regression equation of tensile strength [MPa] $T r$ versus root diameter [mm] of Spanish Broom curve is $\operatorname{Tr}=37.605 d^{-0.306} R^{2}=0.29$. where the coefficient of the power law curve corresponds to the tensile strength for a diameter equal to 1 . Moreover, this value is more meaningful than the average of values measured for comparison both within and between species (Preti, 2006). Norris and Greenwood (2003) and Tosi (2007) found a mean tensile strength value of $17 \mathrm{MPa}$ and $30 \mathrm{Mpa}$, respectively, while Laranci et al. (2004) reported values between 20 and $81 \mathrm{MPa}$ for diameters of presumably up to $2 \mathrm{~mm}$.

In the previous study conducted by Tosi (2007) the humidity of samples was very low (always under 30\%) and was about half the humidity we calculated here (always over $30 \%$ ), both for dry and wet weight. This factor does not seem to influence the tensile strength but only the elastic deformation, although, conventionally, as far as wood is concerned, there are small variations in the mechanical characteristics beyond the threshold of 30\%. Viscoelastic phenomena (rather significant on wet wood and bark) did not occur due to the test rate (Cofie and Koolen, 2001). Roots from naturally regenerated plants could have higher tensile strength than container plants (Lindström and Rune, 1999), whereas no differences have been found yet between cuttings and container grown seedlings (Stokes et al., 2008). 


\section{Root reinforcement and hydrological conditions}

A stability analysis was performed using the infinite slope model (Fig. 10) in order to compare our results with those of other authors who have studied the Spanish Broom (e.g. Tosi, 2007). In the present study other data are provided for the calculation of root reinforcement also with alternative methods as in Schwarz et al. (2009) (Fig. 5).

The slope stability considerably increases with the presence of Spanish Broom. It is to be noticed that the $\mathrm{Cv}$ values are overestimated by using Eq. (2), then similarly the Fs values could be overestimated. In the case of transplanted plants the value of $F s$ is affected by the limited depth reached by the roots and shows its effect only in the first $35-40 \mathrm{~cm}$. The analysed spontaneous plants have deeper roots and also the horizontally explored surface is larger but the density lower. This is probably due to the minor competition and to the growth in a natural soil since the first years of life. We can state that on a natural slope with a continuous covering of Spanish Broom, as we can find in the Apennines, a high additional cohesion is provided to the soil (Fig. 10). The Fs values obtained in saturated conditions harmonized satisfactorily with the measured landslide scarp (Fig. 2) and with Tosi's results (2007) from the clay slopes of the Apennines. We obtained satisfactory agreement between the statistically estimated occurrence return time of the rainfall event occurred and the calculated one by means of the stability model.

The presence of many roots in a limited soil thickness and the presence of many plants covering the slope create a considerable protection of the soil. The covering offered by the crown with the current square layout is $100 \%$ and the plants reach the height of $2 \mathrm{mt}$ after about six years since the planting. Actually naturally regenerated and direct sown seedlings are the most mechanically stable and more difficult to uproot and the soil stabilization is probably due to a well developed and undisturbed root system (Halter and Chanway, 1993; Lindström and Rune, 1999, Stokes et al., 2008).

\section{Spanish Broom propagation}

Under ideal conditions, Spanish Broom has a high germination rate, as do all legumes (Piotto and Di Noi, 2001) and can also be micropropagated. In fact, Spanish Broom is commonly used to restore greenery on slopes by using plants with root balls or bare roots, a method that leads to excellent rooting-taking results. In a recent study concerning the reforestation of marginal areas (La Mantia and La Mela Veca, 2004) 369 bare-root plants were used. After 4 years, the survival rate was $93.8 \%$, with an average height of $1.70 \mathrm{~m}$. Spanish Broom can develop a crown of up to 60 to $80 \mathrm{~cm}$ in 14 months (Laranci et al., 2004).

In our study Spanish Broom plants had a very high survival rate when planted with a root ball. Root-ball plants gave excellent results and created dense land cover. The canopy increased rapidly and did not allow other species to grow. The percentage of rooting in stem cuttings was very low (almost zero). If rooting takes place, development only occurs in the area around the cut and not along the stem (Fig. 11). Rooting is only possible with particular treatment and care. This method is inappropriate where the need exists to allow plants to grow autonomously (AA.VV., 2006).

As far as the architecture of the root system that develops from a cutting is concerned, it was clearly not possible to verify whether there are any differences when using agamic propagation. We can nevertheless state that in the rooted cutting in Fig. 11 it was possible to observe a large number of small roots, in contrast to what was found in plants more than 5- to 6-years-old. This is probably due to the phenological phase of adventitious root emission for survival. We presume that with further development the root system assumes the characteristic conformation of this species. Close observation of Fig. 11 revealed that among all the roots, there were three or four that prevailed over the others, in particular one vertical and two horizontal roots, which would probably later constitute the main branches.

The essential difference between seedlings and cuttings is that the latter can develop a taproot only after five years (Khuder et al., 2007). Plants which were generated from cuttings are usually smaller and have a lower number of roots than the seeds grown ones. Cuttings do not generate laterally and vertically with the same facility, at least in young plants. Cuttings uprooting is easier than seedlings uprooting at the same age, but these differences may disappear after several years (Khuder et al., 2007).

\section{Conclusions}

The measurement and calculation of mean root number, mean root diameter, RAR, tensile strength, root cohesion and Factor of safety in saturated conditions have been carried out for transplanted and spontaneous plants. The indirect RAR estimation methodology correlated well with the direct measurements. By applying the $\mathrm{Wu}$ and Waldron formula, it was found that planting a steep slope with Spanish Broom brings about a considerable increase in cohesion in the surface layers of the soil. In transplanted plants we found an increased cohesion over $40 \mathrm{~cm}$ of depth, almost six years after planting, while we found it over $70 \mathrm{~cm}$ of depth with spontaneous plants of the same age, grown in a natural slope.

The Spanish Broom is a species capable of adapting to types of soil characterized as dry and clayey. When the plant grows in clumps, it tends to prevent the growth of other plants, due to the wide ground coverage of its crown. Spanish Broom can also be used to control erosion because of this thick coverage, which greatly reduces the effect of driving rain. Its root system has a tap root structure. Its aboveground part has a negligible weight as far as overload is concerned.

The rooting tests showed that, plants with root balls give excellent results: $100 \%$ of all plants with root balls had 
rooted. They had created a dense land cover and a network of root systems that significantly reduce soil erosion. Almost two years after planting, 92.7\% stem cuttings had died, whether treated or not with rooting hormone. Consequently, seed propagation in the nursery and micro propagation in the laboratory are the only reproduction techniques that give good results. Agamic field reproduction of Spanish Broom can be ruled out for technical reasons, despite the fact that we did achieve rooting in controlled conditions. The fact that the plant is resistant to burial makes it feasible for use in soil bio-engineering in the Mediterranean climate, even though it does not facilitate the triggering of natural plant succession.

Finally, Spanish Broom has good bio-mechanical characteristics, even in critical pedoclimatic conditions and on steep slopes. It is most appropriate for use in soil bio-engineering aimed at plant adaptability and ground nailing rather than in endeavours where root reinforcement within the structures is required or where natural thick vegetation cover is desired.

Acknowledgements. Our special thanks to: Andrea Dani PostDoc at our Department, Marco Togni of the Laboratories of Wood Technology, Department of Forest Environmental Sciences and Technologies, University of Florence; Pietro Vannocci, Chief Technician in the Engineering Geology Laboratory at the University of Florence, who collaborated in field and lab measurements.

This research was supported by the following Projects: PRINMIUR (Italian Ministry for University and Research) "Sistemi di monitoraggio e modelli per lo studio dei processi di eco-idrologia a diverse scale spazio-temporali", Interreg IIIB Medocc "BVM Bassins Versants Mediterraneens" and ARSIA (Agenzia Regionale Sviluppo Innovazione Agricoltura-Toscana) "Progetto di ricerca inerente la relazione tra gestione selvicolturale e stabilità dei versanti'.

The presentation of the paper at the 2nd International Conference on "Ground Bio- and Eco-engineering. The Use Of Vegetation to Improve Slope Stability” held in Beijing, China, 14-18 July 2008, received the prize for Best Poster, based on scientific quality and aesthetic appearance.

Edited by: F. Laio

\section{References}

AA.VV.: Manuale di coltivazione e prima lavorazione della ginestra per uso tessile. Istituto di Biometeorologia del Consiglio Nazionale delle Ricerche, Regione Toscana, ISBN: 8890146044 , 52 pp., 2006 (in Italian).

Abernethy, B. and Rutherfurd, I. D.: The distribution and strength of riparian tree roots in relation to riverbank reinforcement, Hydrol. Process, 15, 63-79, 2001.

Amato, M., Pardo, A., Faretta, S., and Quaglietta Chiaranda', F.: Misura della resistenza alla trazione delle radici un contributo alla determinazione dell'effetto delle piante sulla stabilità del terreno, Rivista di Agronomia, 31(2), 762-767, 1997 (in Italian).

Amato, M., Di Martino, P., Di Pasquale, G., Mazzoleni, S., Migliozzi, A., and Strumia, S.: Il ruolo della vegetazione nelle frane di Quindici, Quaderni di Geologia Applicata, 7(1), 97-108, 2000 (in Italian).

Bagnaresi, U., Bignani, C., and Chiusoli, A.: Ricerche sull'impiego di arbusti per il rivestimento di scarpate argillose, L'Italia Forestale e Montana, 41(4), 165-182, 1986 (in Italian).

Bischetti, G. B., Chiaradia, E. A., Simonato, T., Speziali, B., Vitali, B., Vullo, P., Zocco, A.: Root strength and root area of forest species in Lombardy (Northern Italy), Plant Soil, 278, 11-22, 2005.

Bohm, W.: Methods of studying root systems, New York: SpringerVerlag, 194 pp., 1979.

Burroughs, E. R. and Thomas, B. R.: Declining root strength in Douglas fir after felling as a factor in slope stability, USDA For. Serv. Res., INT-190, 27 pp., 1977.

Cervelli C.: Le specie arbustive della macchia mediterranea, Collana Sicilia Foreste, suppl., 26, 181 pp., 2003 (in Italian).

Chiatante, D., Scippa, G. S., Di Iorio, A., and Sarnataro, M.: Root architecture modified by mechanical stress in seedlings of Fraxinus ornus L. and Spartium junceum L. growing on slopes, in: Proceedings of the international conference on forest research: a challenge for an integrated European approach, edited by: Radoglou, K., Thessaloniki, Greece, 477-482, 2001.

Chiatante, D., Sarnataro, M., Fusco, S., Di Iorio, A., and Scippa, G. S.: Modification of root morphological parameters and root architecture in seedlings of Fraxinus ornus L. and Spartium junceum L. L. growing on slopes, Plant Growth Regul., 21, 247260, 2003a.

Chiatante, D., Sarnataro, M., Fusco, S., Di Iorio, A., and Scippa, G. S.: Modification of root morphological parameters and root architecture in seedlings of Fraxinus ornus L. and Spartium junceum L. growing on slopes, Plant Biosyst., 137(1), 47-55, 2003 b.

Cofie, P. and Koolen, A. J.: Test speed and other factors affecting the measurements of tree root properties used in soil reinforcement models, Soil Till. Res., 63, 51-56, 2001.

Coppin, N. J. and Richards, I. G.: Use of vegetation in civil engineering, Butterworth, London, 272 pp., 1990.

Dani, A. and Preti, F.: Sulla stima del rinforzo radicale del terreno: andamenti temporali ed effetti sulla stabilità abilità di versante con trattamenti selvicolturali, Quaderni di Idronomia Montana, Nuova Editoriale Bios, 27, 295-309, 2007 (in Italian).

De Baets, S., Poesen, J., Knapen, A., Barberá, G. G., and Navarro, J. A.: Root characteristics of representative Mediterranean plant species and their erosion-reducing potential during concentrated runoff, Plant Soil, 294, 169-183, 2007.

De Baets, S., Poesen, J., Reubens, B., Wemans, K., De Baerdemaeker, J., and Muys, B.: Root tensile strength and root distribution of typical Mediterranean plant species and their contribution to soil shear strength, Plant Soil, 305, 207-226, 2008.

Di Iorio, A., Lasserre, B., Scippa, G., and Chiatante, D.: Root system architecture of Quercus pubescens trees growing on different sloping conditions, Ann. Bot.-London, 95(2), 351-361, 2005.

Fan, C. C. and Su, C. F.: Role of roots in the shear strength of root reinforced soils with high moisture content, Ecol. Eng., 3, 157166, 2008.

Gallotta, A.: Contributo della vegetazione alla stabilità dei suoli declivi in ambiente mediterraneo, Dissertazione per il conseguimento del titolo di Dottore di Ricerca in Idronomia, Ist. Di Sistemazioni idraulico-forestali, Bari, sede amministrativa Univer- 
sità degli Studi di Padova, 95 pp., 2000 (in Italian).

Gallotta, A., Gentile, F., Puglisi, S., and Romano, G.: Primi risultati di una ricerca sulla resistenza meccanica degli apparati radicali nella stabilizzazione dei versanti in ambiente mediterraneo, Collana Quaderni Idronomia Montana, ISBN: 88-7740-341-1, 21(1), 382 pp., 2003 (in Italian).

Genet, M., Stokes, A., Salin, F., Mickovski, S. B., Fourcaud, T., Dumail, J. F., and Beek, R.: The influence of cellulose content on tensile strength in tree roots, Plant Soil, 278, 1-9, 2005.

Gray, D. H. and Leiser, A. T.: Biotechnical slope protection and erosion control, Van Nostrand Reinhold Co, New York, 271 pp., 1982.

Gray, D. H. and Sotir, R. D.: Biotechnical and soil bioengineering slope stabilization, John Wiley and Sons, NY, 369 pp., 1996.

Greenway, D. R.: Vegetation and slope stability, in: Slope stability, edited by: Anderson, M. G. and Richards, K. S., John Wiley \& Sons Ltd, New York, 187-230, 1987.

Greenwood, J. R.: SLIP4EX - A program for routine slope stability analysis to include the effects of vegetation, reinforcement and hydrological changes, Plant Soil, 24, 449-465, 2005.

Halter, M. R. and Chanway, C. P.: Growth and root morphology of planted and naturally regenerated Douglas-fir and lodgepole pine, Ann. Sci. Forest., 50, 71-77, 1993.

Hartmann, H. T., Kester, D. E., Davies, F. T, and Geneve, R. L.: Plant propagation: principles and practices, 7th edn., Prentice Hall, Upper Saddle River, NJ, 769 pp., 2002.

Khuder, H., Stokes, A., Danjon, F., and Gouskou, K.: Is it possible to manipulate root anchorage in young trees, Plant Soil, 294, 87$102,2007$.

Laio, F., D’Odorico, P., and Ridolfi, L.: An analytical model to relate the vertical root distribution to climate and soil properties, Geophys. Res. Lett., 33, L18401, doi:10.1029/2006GL027331, 2006.

La Mantia, T. and La Mela Veca, D. S.: L'impiego della ginestra di spagna in intervent di forestazione di aree marginali: il caso studio dei Monti Sicani (AG), Italus Hortus, luglio-agosto, 11(4), 116-119, 2004 (in Italian).

Laranci, P., Dallari, D., Amato, M., Petelli, M., and ScarasciaMugnozza, G.: Capacità di radicazione e proprietà biotecniche di alcuni arbusti ed alberi mediterranei (per il recupero ecologico di ambienti degradati), Rivista di Ingegneria Agraria, Pisa, Edizioni ETS, p. 2, 9-16, 2004 (in Italian).

Leopardi, G.: La Ginestra o il fiore del deserto, in: a cura di Nicolò Gallo e Cesare Garboli, edited by: Canti, G. L., Torino: Einaudi, copyr. 1993 LXXIII, ISBN: 88-06-13303-9, 447 pp., 1845.

Lindström, A. and Rune, G.: Root deformation in containerised Scots pine plantations - effects on stability and stem straightness, Plant Soil, 217, 29-37, 1999.

Mattia, C., Bischetti, G. B., and Gentile, F.: Biotechnical characteristics of root systems of typical Mediterranean species, Plant Soil, 278, 11-22, 2005.

Morone Fortunato, I., Ruta, C., and Tagarelli, A.: Different species of broom and related propagation protocols [Cytisus scoparius (L.) Link; Spartium junceum L.; Genista aspalathoides Lam.], Italian Horticultural Society (SOI), national meeting on biodiversity, 7, Catania, Italy, 31 March-2 April 2005, 2005.

Norris, J. E. and Greenwood, J. R.: Root reinforcement on unstable slopes in Northern Greece and Central Italy, International Conference on Problematic Soils, Nottingham Trent University,
Nottingham, UK, 411-418, July 2003.

Norris, J. E., Stokes, A., Mickovski, S. B., Cammeraat, E., van Beek, R., Nicoll, B. C., and Achim, A. (Eds.): Slope Stability and Erosion Control: Ecotechnological Solutions VI, Hardcover, ISBN: 978-1-4020-6675-7, 290 pp., 2008.

O'Loughlin, C. L. and Watson, A. J.: Root-wood strength deterioration in Radiata Pine after clearfelling, New Zeal. J. For. Sci., 39(3), 284-293, 1979.

Operstein, V. and Frydman, S.: The influence of vegetation on soil strength, Ground Improv., 4, 81-89, 2000.

Piotto, B. and Di Noi, A.: Propagazione per seme di alberi e arbusti della flora mediterranea, ANPA (Agenzia Nazionale per la Protezione dell' Ambiente Dipartimento Prevenzione e Risanamento Ambientali, ITALIA), 2001 (in Italian).

Preti, F. and Schwarz, M.: On root reinforcement modelling, The role of vegetation in slope stability and mitigation measures against landslides and debris flows, EGU General Assembly, 2-7 April 2006, Geophys. Res. Abstr., 8, 04555, 2006.

Preti, F., Dani, A., and Laio, F.: Root profiles assessment by means of hydrological, pedological, and aboveground vegetation data for bioengineering purposes, Ecol. Eng., doi:10.1016/j.ecoleng.2009.07.010, in press, 2009.

Preti, F.: Stabilità dei versanti vegetati, Cap. 10, in: Manuale 3 d'Ingegneria Naturalistica Sistemazione dei versanti, edited by: Sauli, G., Cornelini, P., and Preti, F., Regione Lazio, Roma, 137-168, http://www.regione.lazio.it/web2/contents/ingegneria_ naturalistica/manuale_versanti/Cap_10_10.pdf, 2006 (in Italian).

Pollen, N. and Simon, A.: Estimating the mechanical effects of riparian vegetation on streambank stability using a fiber bundle model, Water Resour. Res., 41, W07025, doi:10.1029/2004WR003801, 2005.

Quatrini, P., Scaglione, G., Cardinale, M., Caradonna, F., and Puglia, A. M.: Bradyrhizobium sp. nodulating the Mediterranean shrub Spanish broom (Spartium junceum L.), J. Appl. Microbiol., 92, 13-21, 2002.

Regione Toscana: Aggiornamento e sviluppo del del sistema di regionalizzazione delle portate di piena in Toscana AlTo, http://www.rete.toscana.it/sett/pta/suolo/difesa_suolo/alto/ index.htm, 2007 (in Italian).

Riestenberg, M. M.: Anchoring of thin colluvium by roots of Sugar maple and White ash on a hillslope in Cincinnati, US Geological Survey Bulletin, 2059-E, 1-25, 1994.

Schwarz, M., Preti, F., Giadrossich, F., Lehmann, P., and Or, D.: Quantifying the role of vegetation in slope stability: A case study in Tuscany (Italy), Ecol. Eng., doi:10.1016/j.ecoleng.2009.06.014, in press, 2009

Schenk, H. J. and Jackson, R. B.: The Global Biogeography of Roots, Ecol. Monogr., 72(3), 311-328, 2002a.

Schenk, H. J. and Jackson, R. B.: Rooting depths, lateral root spreads and below-ground/above-ground allometries of plants in water-limited ecosystems, J. Ecol., 90, 480-494, 2002b.

Schmid, I. and Kazda, M.: Vertical distribution and radial growth of coarse roots in pure and mixed stands of Fagus sylvatica and Picea abies, Can. J. Forest Res., 31, 539-548, 2001.

Schmid, I. and Kazda, M.: Root distribution of Norway spruce in monospecific and mixed stands on different soils, Forest Ecol. Manag., 159, 37-47, 2002.

Schmidt, K. M., Roering, J. J., Stock, J. D., Schaub, T., Dietrich, W. E., and Montgomery, D. R.: The variability of root cohesion 
as an influence on shallow landslide susceptibility in the Oregon Coast Range, Can. Geotech. J., 38, 995-1024, 2001.

Sidle, R. C., Pearce, A. J., and O’Loughlin, C. L.: Hillslope stability and land use, Water Resour. Monogr. Ser., AGU, Washington DC, 11, 140 pp., 1985.

Sidle, R. C.: A theoretical model of the effects of timber harvesting on slope stability, Water Resour. Res., 28, 1897-1910, 1992.

Stokes, A., Abd Ghani, M., Salin, F., Danjon, F., Jeannin, H., Berthier, S., Kokutse, A. D., and Frochot, H.: Root morphology and strain distribution during tree failure on mountain slopes, in: Eco- and ground bio-engineering: the use of vegetation to improve slope stability, Developments in Plant and Soil Sciences, edited by: Stokes, A., Spanos, I., Norris, J. E., and Cammeraat, L. H., Springer Publishers, Dordrecht, ISBN-10: 1-4020-5592-7, ISBN-13: 978-1-4020-5592-8, 103, 165-173, 2007.

Stokes, A., Norris, J. E., van Beek, L. P. H., Bogaard, T., Cammeraat, E., Mickovski, S. B., Jenner, A., Di Iorio, A., and Fourcaud, T.: How vegetation reinforces soil, in: Slope stability and erosion control: Ecotechnological solutions, edited by: Norris, J. E., Stokes, A., Mickovski, S. B., Cammeraat, E., Van Beek, R., Nicoll, B. C., and Achim, A., Springer, 65-118, 2008.

Tosi, M.: Root tensile strength relationships and their slope stability implications of three shrub species in the Northern Apennines (Italy), Geomorphology, 87, 268-283, 2007.
Vogt, K. A. and Persson, H.: Root methods, in: Techniques and Approaches in Forest Tree Ecophysiology, edited by: Lassoie, J. P. and Hinckley, T. M., CRC Press, Boca Raton, Florida, 477502, 1991.

Waldron, L. J.: The shear stress resistance of root-permeated homogeneous and stratified soil, Soil Sci. Soc. Am. Pro., 41, 843-849, 1977.

Wu, T. H.: Investigation on landslides on Prince of Wales Island, Alaska Geotech Rpt. No 5, Dpt. of Civil Eng., Ohio State Univ., Columbus, USA, 1976.

Wu, T. H.: McKinnell III, W. P., and Swanston, D. N.: Strength of tree roots and landslides on Prince of Wales Island, Alaska, Can. Geotech. J., 16, 19-33, 1979.

Wu, T. H.: Effect of vegetation on slope stability, in: Soil reinforcement and moisture effects on slope stability, Transportation Research Board, Washington, DC, 37-46, 1984a.

Wu, T. H.: Soil movements on permafrost slopes near Fairbanks, Alaska, Can. Geotech. J., 21, 699-709, 1984b.

Wu, T. H. and Sidle, R. C. A.: A distributed slope stability model for steep forested basins, Water Resour. Res., 31(8), 2097-2110, 1995.

Ziemer, R. R.: Roots and stability of forested slopes, Erosion and sediment transport in Pacific Rim Steeplands, IAHS, Pub. No. 132, 343-361, 1981.

Servizio Agrometereologico Regionale, Regione Toscana: http://agrometeo.arsia.toscana.it/, access: 1 May 2009 (in Italian). 